\title{
Sterilizer chamber design with telegram-based internet of things (IoT) applications
}

\author{
Nurwijayanti KN ${ }^{1, *}$, Reza Ananda ${ }^{2}$ \\ ${ }^{1,2}$ Department of Electrical Engineering, Universitas Dirgantara Marsekal Suryadarma
}

\begin{tabular}{l}
\hline \hline Article Info \\
\hline Article history: \\
Received November 10, 2021 \\
Accepted November 26, 2021 \\
Published November 30, 2021 \\
\hline
\end{tabular}

Keywords:

Internet of Things

Telegram

Disinfectan Liquid

Sterilizer Cha mber

Corona Virus

\begin{abstract}
In order to reduce the spread of the corona virus in office areas, malls or housing, a sterilizer chamber is installed. It is used to detect someone who will enter an area and he must be sterilized first by spraying the entire body with disinfectant liquid automatically. By combining the sterilizer chamber tool with IoT technology, the sterilizer chamber tool can be monitored continuously at a certain distance using a sensor as a detector which will provide information to one of the operators of the tool condition, about the remaining liquid, the number of people who have been sterilized. The system works by providing information on the liquid spray time of about 5 seconds and information on the liquid level in the tube from level 5-70. The average output pin voltage is $4.89 \mathrm{~V}$ when the sensor detects an obstacle in front of the sensor and the NODEMCU will receive a voltage $4.89 \mathrm{~V}$ from the output pin and ultrasonic sensor HC-SR04. The highest voltage reaches $673.2 \mathrm{Mv}$, when the distance to the object is $40 \mathrm{~cm}$ with the lowest voltage is $100.3 \mathrm{mV}$ with the closest distance being $5 \mathrm{~cm}$.
\end{abstract}

\section{Corresponding Author:}

Nurwijayanti KN,

Teknik Elektro,

Universita s Dirga ntara Marsekal Suryadarma,

Protokol Halim Perdanakusuma, Bandara Halim PK, Jakarta Timur

Email: nurwijayanti_kn@yahoo.com

\section{INTRODUCTION}

The corona virus or known as COVID-19 has hit Indonesia for a year, exactly since February 2020, to deal with the corona virus, we have to do from prevention to the treatment. The application of $3 \mathrm{M}$ (Washing hands, Wearing Masks and Maintaining Distance) to $5 \mathrm{M}$ (Wa shing hands, Wearing Masks, Ma intaining Distance, Reducing traveling a nd a voiding crowds [1] is still not fully effective in elim in at ing the transmission of the Corona Virus which is increa singly spreading with all its variants [2].

The current problem is how to reduce the spread of thecorona virus, especially in the office a reas, malls or housing, a sterilizer chamber is installed, in order to detect someone who will enter an area, especially closed and a ir-conditioned areas such as office buildings, malls and many more. The people who entered must be sterilized first by spraying the entire body with disinfectantliquid a utomatically, for half a minute or 30 seconds.

Along with advances in technology, especially in the field of telecommunications, as well a s utilizing the wi-fi network that is a lready evenly distributed, especially in both government a nd private offices, some campuses have a lso used wi-fi as a means of communication both data, voice a nd im age, a s well a s IoT (Internet of Think) technology. It has been applied in all fields, even at home, in hotels, in offices, using IoT technology to facilita te a ll activities rela ted to electronic devices [3].

Thus, the purpose of making this sterilizer cha mber toolby combining IoT technology is to red u ce the spread of the corona viru in closed space, especially those with a ir conditioning by detecting how many people have been sprayed and the rest of the disinfectant liquid. It can be monitored at a ny time remotely a s long a it is still affordable with the internet network. IoT devices consist of sensors as data collection media, internet connections a s communication media and servers as information collectors received by sen sors for analysis. The initialidea of the Internet of Things was first raised by Kevin Ashton in 1999 in one of his 
presentations. The sterilizer chamber ca n be monitored continuou sly a t a certain distance, by on e operat or using a sensor a s detector, which will provide information to one of the operators about the condition of the device. The information sent is the remaining disinfectant liquid, the number of people who have been sterilized, and people's body temperature who a re in the room. This tool can work for 24 hours so it is hoped that the spread of the virus during the pandemic will be effectively reduced with a nerror value close to $0 \%$.

\section{RESEARCH METHOD}

The research methods in this study are:

\subsection{Internet of Things}

Internet of things or known as IoT is a term for greater use of the internet, a dopting mobile money computing a nd connectivity and then incorporating it into everyday life. IoT is related to DoT (Disruption of Things) and a s an introduction to the change or transformation of internet use from the previous Internet of People to the internet of M2M(Machine-to-Machine).

IoT technology aims to extend the benefits of continuously connected internet connectivity that allows connecting machines, equipment, a nd other physicalobjects with network sen sors and a ct uat ors to acquire data and manage their own performance.

Figure 1 explain s theIoT concept which is a ctually quite simple with the way it works referring to 3 main elements in the IoTarchitecture, namely: Phy sical Goods equipped with IoT module s, Co nnection Devices to the Internet such as Modems and Speedy Wireless Routers.

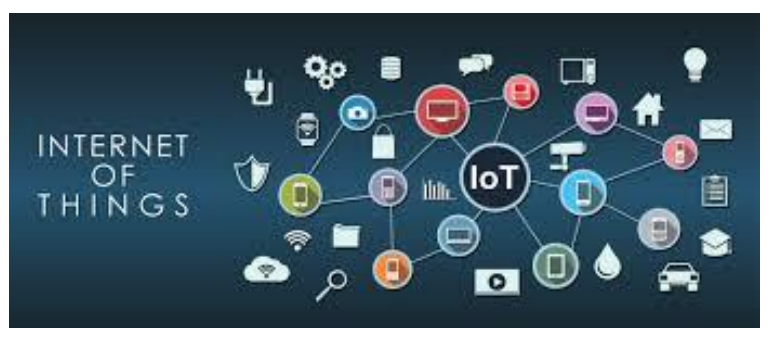

Figure 1. IOT Concept

The basic working principle of IoT devices is that objects in the real world are given a unique identity and can be multiplied in a computer system and can be represented in the form of data in a computer system. At the beginning of the implementation of the idea of IoT, the identifier is used so that tobjects can be identified and read by a computer. In addition, it uses a ba rcode(Barcode), QR Code (QR Code) a nd Radio Frequency Identification (RFID).

\subsection{IoT implementation}

Machines are made to makehuman work easier, at first time, machines were made only to help humans a nd operated manually. As time goes by, the machine can run it self (a ut omatically), but in its development the use of machines as a tool in a system will encounter obstacles when it com es to distance and time. To overcome this case, the idea of the internet of things is applied where all electronic machines/devices can be connected to each other with an IP address identifier using the internet network as a communication medium (exchanging data) [4]. The application is shown in figure 2.

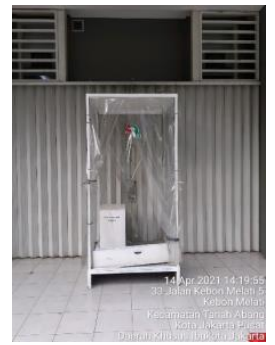

Figure 2. The application of IoT in the sterilizer chamber 
Installing sen sors at several points, one of which is at the entrance and where the liquid is disinfected, at the entrance to find out the number of people who have been sterilized, while the sen sor is at the pla ce where the liquid is disinfected where all sensors will be connected to IoTas information to the operator, for the number of people and to find out the remaining liquid. It is a vailable to be refilled immediately.

\subsection{Open Control System (Open Loop)}

In this Sterilizer Chamber, it uses an open control system. An open loop control system is a control system whose output has no effect on the controlling action. So, in a open loop control system, su ch a s in Figure 3, the output is not measured or feedback to compare with the in put [5].

In any open-loop control system, the output is not compared with the reference input. Thus, for each reference input, there is a constant operating condition.

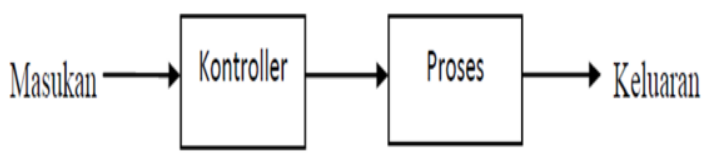

Figure 3. Open Loop Control System

\subsection{Disinfectant Liquid}

A disinfectant is an a ntimicrobial a gent designed to ina ctivate or destroy microorganisms on moist surfaces. Although capable of killing microorga nisms, but notall can die with ju st a dis infectant. Some extreme microorganisms still ha ve to work by destroying microbial cell wa lls or interfering with metabolism [6]. In this Sterilizer Cha mber, Disinfectant is the main ingredient after the Process (Out put), a s shown in Figure 4.

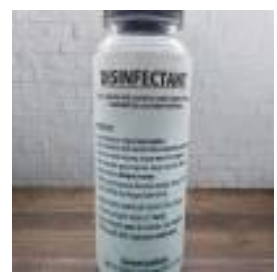

Figure 4. Disinfectant Liquid Image

\subsection{Volume Use of water and disinfectant}

In the use of disinfectants, the volume and amount of wa ter consumption must be consid ere d. By calibra ting the spray tool. It is very important to carry out proper calibration of each type of sprayer, nozzle, and travel speed before starting spraying or at certain times, so that the use of disinfectants becomes efficient and effective, as in formula (1)

$$
D=\frac{100 x C}{(6 X B) x A}
$$

$$
\begin{aligned}
& \text { Calibration Procedure } \\
& \begin{aligned}
D & =\text { Spray Volume } \\
A & =\text { Mea sure the a verage spray width (meters) } \\
B & =\text { Mea sure the distance }(\mathrm{m}) \text { by the operator for } 10 \text { seconds } \\
C & =\text { Mea sure Output or flow ra te (litters } / \text { minute) at optimum pump pressure }\left(1 \mathrm{~kg} / \mathrm{cm}^{2}\right)
\end{aligned}
\end{aligned}
$$

The following is the calculation of the need for spray volume (liters/Number of People) by referring to formula (1):

$$
D=\frac{100 x C}{(6 X B) x A} \text { or Liters/number of people come }
$$




\section{$=\frac{100 x \text { liter / menitoutput }}{(6 x \text { Rangem } / 10 \text { Second }) x \text { SprayWidth }}$}

Example:

$A=$ Avera ge spray width is 1 meter

$\mathrm{B}=$ Avera ge walking distance is 0.5 meters per 5 seconds

$\mathrm{C}=$ Avera ge spray output is 1 litter/minute

$\mathrm{D}=$ What is the spray volume(litters / Number of people)

$D=\frac{100 \times 1}{(6 \times 25) \times 1}=\frac{100}{15}=6,6$ Liter 100 People's

It can be concluded that the Volume of Disinfectant Spray and Water for 100 people is 6.6 Litters or per 1 person to $66 \mathrm{ml}$.

\subsection{NodeMCU}

NodeMcu is an open source IoT platform and development kit that u ses the Lua programming language to help programmers create prototy pes of IoT products or can use sketches with the Arduin o IDE. This development kit is based on the ESP8266 module, which integrates GPIO, PWM (Pulse Width Modulation), IIC, 1-Wire and ADC (Ana log to Digital Converter) all in one board [7].

NodeMcu in Figure 5 is one of the products that has special rights from Arduino to be able to use Arduino applications so that the programming la nguage used is the same as Arduino boards in general.

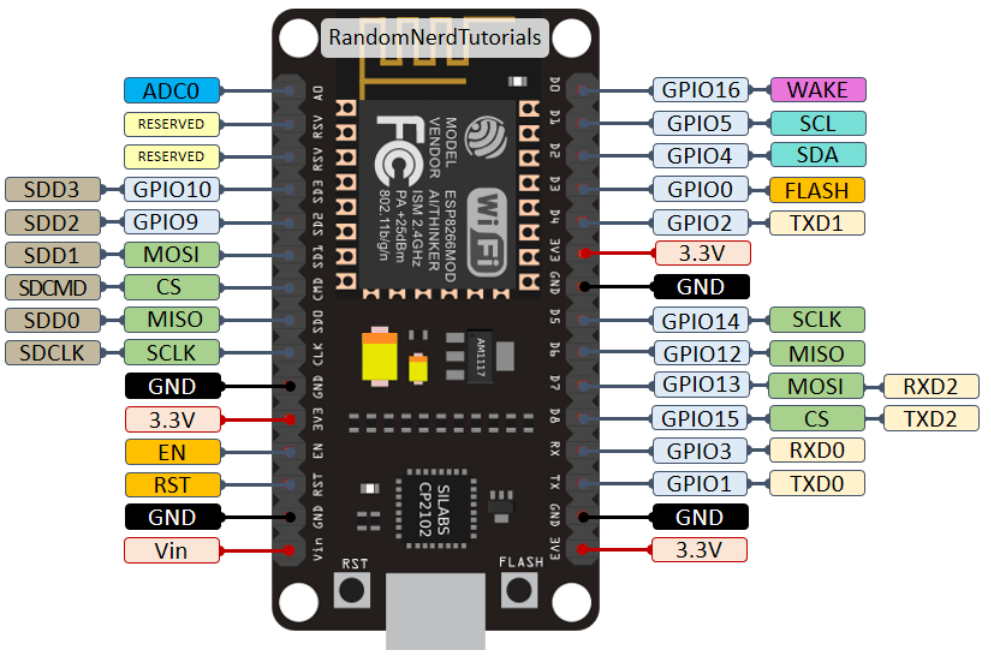

Figure 5. Mapping NodeMCU

\subsection{Ultra-sonic HC-SR04}

This type of sensor is an electronic module that detects an object using sound. The ultrasonic sensor consists of a transmitter (transmitter) and a receiver (receiver) [8]. Transmitter serves to emit a sou nd wa ve towards the front. If there is an object in front of the transmitter, the signal will bounce back to the receiver, like in Figure 6.

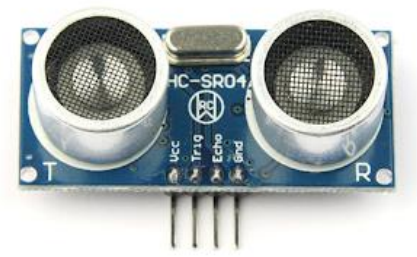

Figure 6. Sensor Ultrasonic HCSR04 


\subsection{Inf rared e18-D80NK}

The E18-D 80NK is an infrared proximity sensor, this tool has a detection range that can be adjusted from $3 \mathrm{~cm}$ to $80 \mathrm{~cm}$ with NPN output [9], the tool is small and easy to use and easy to a ssemble and the relatively affordable price. It is one of the reasons to choose this tool. It is shown in Figure 7, the examples of robots, interactive medians, ind ustry and others.

This sensor does not need direct contact with the instrument, only by infrared shots at the object to be measured.

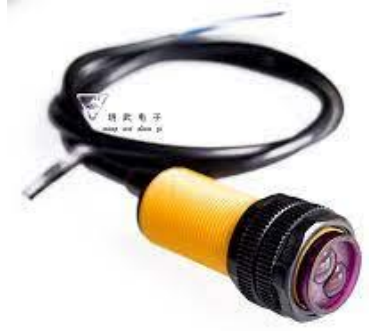

Figure 7. Infrared Sensor

\subsection{LCD}

LCD (Liquid Crystal Display) is a type of display media that uses liquid crystals as the main display. LCD has been u sed in various fields such as electronic devices such a s televisions, ca lcula tors, or computer screens. The LCD has a function a s a viewer which will later be used to display the working status of the tool[10], a s shown in Figure 8.
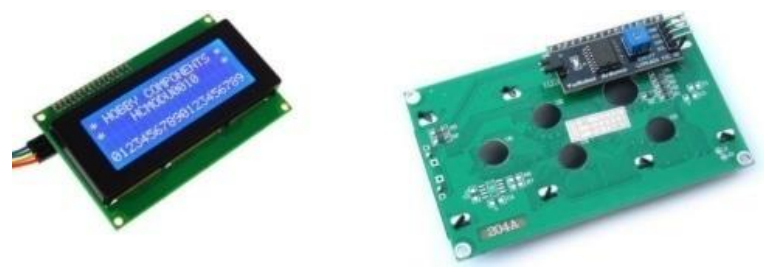

Figure 8.20x4 LCD Character Display with I2 Cmodule

The LCD used is $20 \mathrm{x} 4$ character LCD with an additional I2C chip module to make it ea sier for programmers to access the LCD later.

\subsection{I2C Module}

The I2C module is a two-way serial communication standard using two channels specifically designed to send a nd receive data, as shown in Figure 9 [11]. The I2C system consists of SCL (Seria 1Clock) and SDA (Serial Data) channels that carry data information between I2C and its con troller [12]. Devices connected to the I2C Bus system can be operated as Master and Sla ve. Master is a device that initia tes data transfer on the I2CBus by generating a Start signal, ending data transfer by generating a St op signa l, a nd generating a clock signal.

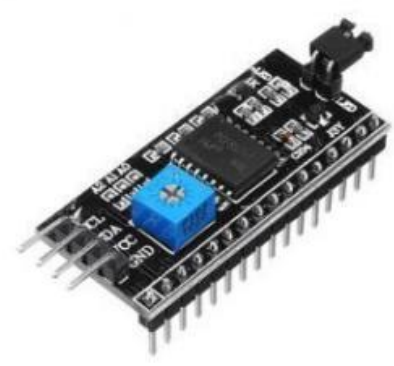

Figure 9. Physical Form of I2C 


\section{RESULTS AND ANALYSIS}

The material to be discussed is a block diagram of the entire sy stem from design to testing.

\subsection{System Block Diagram}

Figure 10 depicts the entire apparatus system of the Sterilizer Chamber.

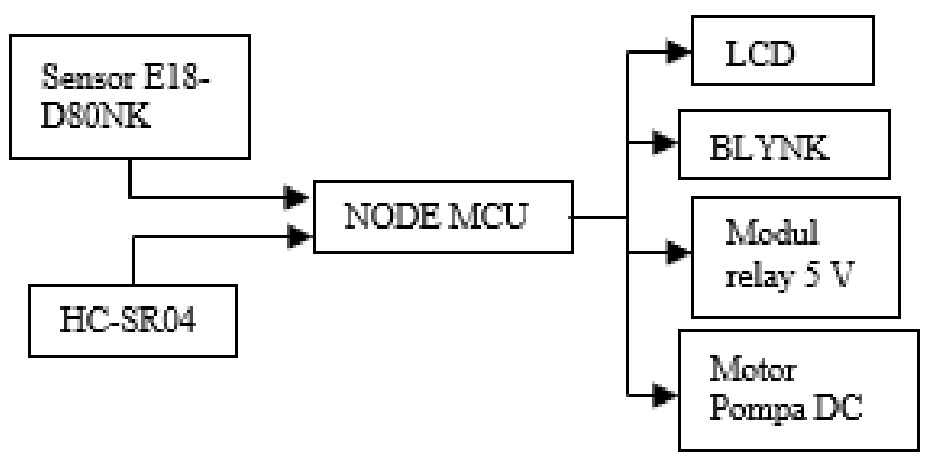

Figure 10. Block Diagram System

From the description of theblock diagram in Figure 10 a bove, it can be explained how it works.

1) NODEMCU is to control all the components so that the system can run according to the program that has been made.

2) LCD 4x20 serves for monitoring to make it visible and controlled.

3) 12 Volt Power Supply is a s the main power source to turn on the tool.

4) Relay module serves to turn on the DC pump motor with a n in put voltage of 12 volts.

5) DC pump motor serves to remove the sterilizing liquid in the tube [13].

6) Sensor HC-SR04 serves to detect the water level in the sterilized water tube.

7) Blynk has function to make the state of the tool can be monitored remotely via a smartphone [14].

\subsection{Flowchart}

The flow of the booth making process can be seen in Figure 11, where the sen sor reads the presence of high/low voltage to the relay to count the number of people entering the booth using the BLYNK application, followed by a nultrasonic sensor to read the distance from the spray to the object(human).

After spraying, the residual/level of the disinfectant liquid will be seen, if it is OUT then there will be a notification "Out of Water". 


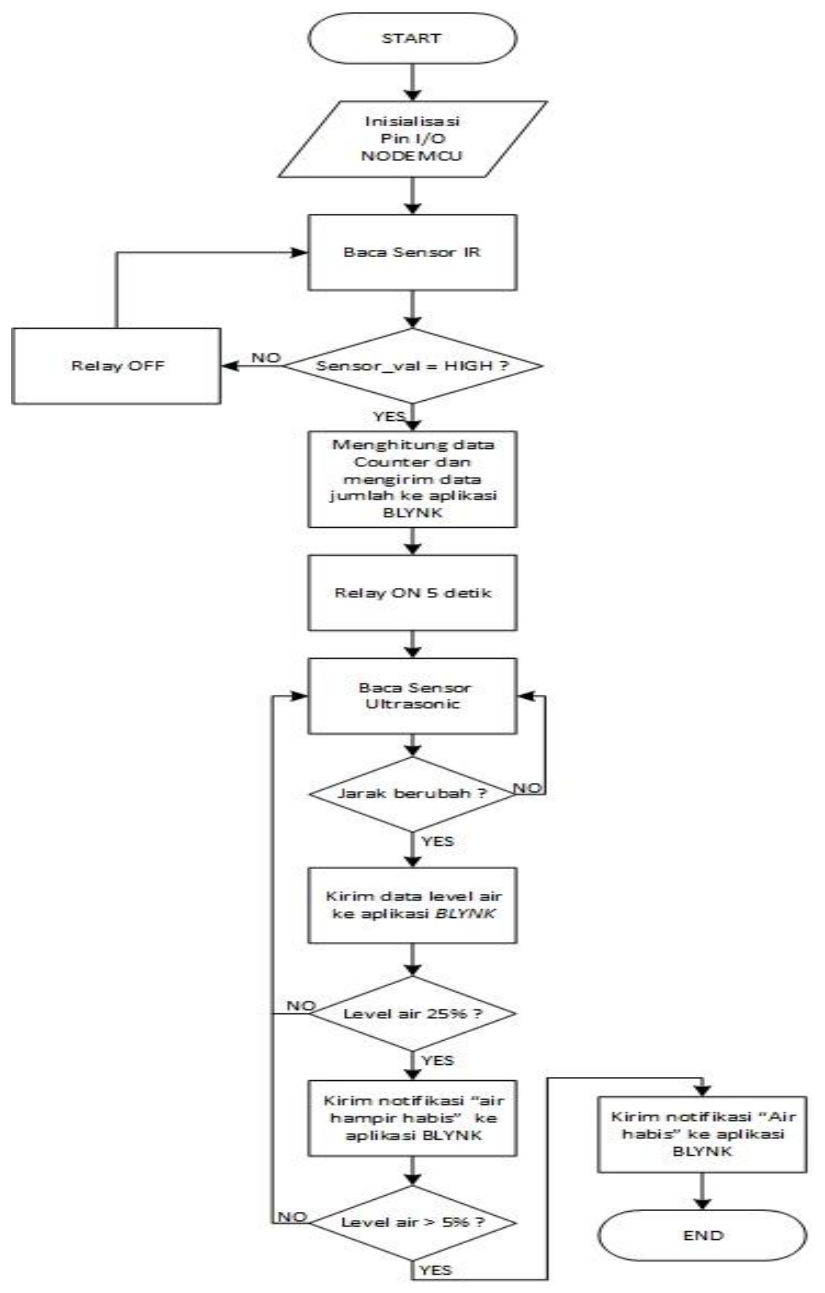

Figure 11. Flowchart System

\subsection{Tool Design}

In this stage, all components will be insta lled in accordance with the system circuit that has been made in the previous stage. LCD, Relay, Ultra sonic Sensor, Nodemcu, and Infrared sen sor will be connected in a circuit and will be loaded in a place so that the components are protected from water, a s shown in Figure 12.

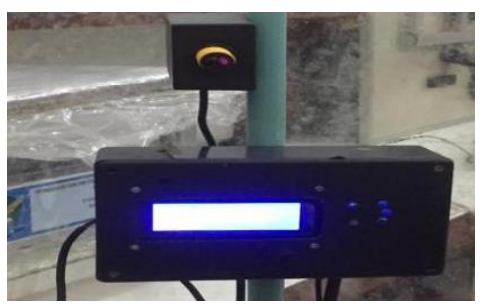

Figure 12.System Box on the Pole

Figure 13 is the infrared system which is stored to make it waterproof when exposed to disinfectant spray. 


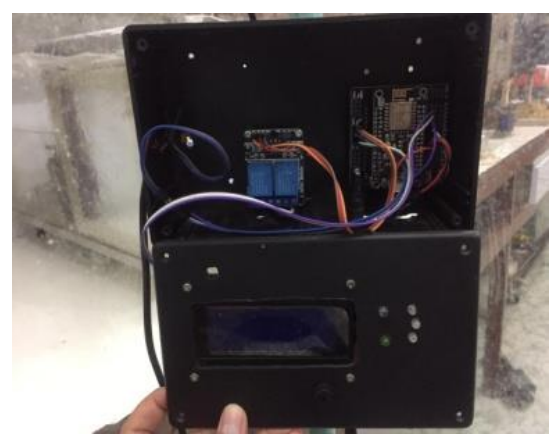

Figure 13. Infrared box

Figure 14 is a booth that will be installed in front of an office building, so that everyone who enters will be sprayed first in the booth.

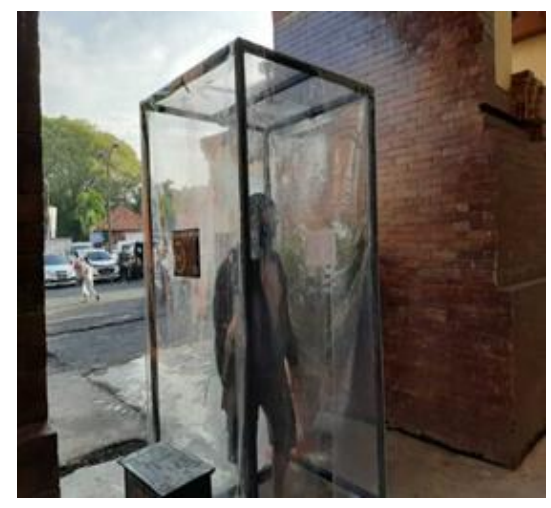

Figure 14. Sterilizer Chamber

After that, it will be proceeded with testing the toolafter the tool is successfully a ssembled. The testing is carried out on ea ch component.

\subsection{Testing Tool}

The next stage is to test this tool as a whole, so that it ca n be seen whether the system on this tool is running a ccording to the programmed commands or not.

1. Testing the E18-D80NK Infrared Sensor

This test is carried out to determine the level of accuracy of the sensor to some predetermin ed distance. This test is carried out by determining several points of distance. First, it uses a meter and then it is given an obstacle according to the target. After that counting, it is to count the number of people who enter the booth.

The distance data obtained from the reflected infrared light will be processed by NODEMCU to a naly ze the sensitivity level, as shown in Table 1

Table 1. Sensor Test

\begin{tabular}{cccc}
\hline NO & Distance $(\mathbf{c m})$ & Status & Output Sensor $(\mathbf{m V d c})$ \\
\hline $\mathbf{1}$ & 0 & No Obstacle & 0 \\
$\mathbf{2}$ & 5 & Obstacle Available & 100,3 \\
$\mathbf{3}$ & 10 & Obstacle Available & 177,8 \\
$\mathbf{4}$ & 20 & Obstacle Available & 345,4 \\
$\mathbf{5}$ & 30 & Obstacle Available & 508,9 \\
$\mathbf{6}$ & 40 & Obstacle Available & 673,2 \\
\hline
\end{tabular}




\section{Ultrasonic HC-SR04 Sensor Testing}

This test is carried out with the aim of knowing the level of accuracy of the sen sor in mea suring a distance. This test is carried out by providing a barrier at the front of the sensor and will be changed periodica lly at several distance points that have been determined in Table 2 .

Table 2. Water leveldistancetest

\begin{tabular}{cclc}
\hline NO & Distance $(\mathrm{cm})$ & \multicolumn{1}{c}{ Status } & $\begin{array}{c}\text { Output Sensor } \\
(\text { Vdc })\end{array}$ \\
\hline 1 & 0 & No Obstacle & 0 \\
2 & 20 & Obstacle Available & 4,89 \\
3 & 40 & Obstacle Available & 4,90 \\
4 & 60 & Obstacle Available & 4,89 \\
5 & 70 & Obstacle Available & 4,89 \\
\hline
\end{tabular}

From the table above, it can be concluded that the farther the distance of the water level(obstacle) which is read by the ultrasonic sensor HC-SR04, the greater the voltage sent by the sensor output pin to the NODEMCU digital pin.

\section{Testing the whole tool}

This test is to find out how accurate the sterilizer chamber system is using the NODEMCU microcontroller, where this section is very important to reduce errors and delays, in Table 3 .

From the test results, all systems can run, the duration of communication between the NODEMCU and the BLYNK application is strongly influenced by the internet signal or not on both devices is strong.

The ultra sonic sensor works well in detecting the water level in the tube, as well a s the in fra red sen sor which can quickly detect the presence of objects so that the system can work quickly.

Table 3. Output measurement on Arduinouno.

\begin{tabular}{cccccc}
\hline Status & Level air & Sensor E18 & $\begin{array}{c}\text { Delay with } \\
\text { distance 27 KM }\end{array}$ & Spray time & Description \\
\hline Empty & 70 & $0 \mathrm{~V}$ & 5,39 Seconds & Not Active & Counting Off \\
Available & 70 & $4.89 \mathrm{~V}$ & 5,89 Seconds & Active 5seconds & Active Counting \\
Available & 25 & $4.90 \mathrm{~V}$ & 6,89 Seconds & Active 5seconds & Active Counting \\
Available & 40 & $4.89 \mathrm{~V}$ & 7,56 Seconds & Active 5seconds & Active Counting \\
Available & 5 & $4.89 \mathrm{~V}$ & 5,13 Seconds & Active 5seconds & Active Counting \\
\hline
\end{tabular}

From the test results above, all systems can run, the duration of fast communication bet ween the NODEMCU and the BLYNK application is strongly influenced by the internet signal or not on both devices is strong.

The ultra sonic sen sor works well in detecting the water level in the tube, as well a s the infra red sensor which can quickly detect the presence of objects so that the system ca n work quickly.

\section{CONCLUSION}

The IoT system has worked well by providing information in realtime, namely the liquid spray time of about 5 seconds and information on the height of the remaining liquid in the tubefrom level 5-70. The sensor sends data to the MCU Node with an average output pin voltage of $4.89 \mathrm{~V}$ when the sensor detects an obstacle in front of the sensor.

The farther the distance rea d by the ultrasonic sen sor Ultra sonic sensor HC-SR04, the greater the volta ge sent by the sen sor ou tput pin to the NODEMCU digital pin, the highest voltage re a ches $673.2 \mathrm{mV}$ when the distance to the object is $40 \mathrm{~cm}$, and the voltage will decrea se. when the distance that is rea $\mathrm{d}$ is close, i.e., with the lowest voltage is $100.3 \mathrm{mV}$ with the closest distance is $5 \mathrm{~cm}$. 


\section{ACKNOWLEDGEMENTS}

I hereby declare that this journal is the original result of my research and that of my colleagues, I thank the Head of the Electrical Engineering Study Program who has supported this research.

\section{REFERENCES}

[1] Nurul Hidayah Nasution, Arinil Hidayah, Khoirunn isa Mardiah Sari, Wirda Cahyati, Mar'atun Khoiriyah, and Riska Putriana Hasibuan, "GAMBARAN PENGETAHUAN MASYARAKAT TENTANG PENCEGAHAN COVID-19 DI KECAMATAN PADANGSIDIMPUANBATUNADUA, KOTA PADANGSIDIMPUAN," Jurnal Kesehatan Ilmiah Indonesia, vol. 6, no. 1, pp. 107-114, 2021.

[2] O. L. Nuryanti, A. Primasuari, L. M. Putri, and A. E. Bakti, "EFEKTIFITAS DiSINFEKTAN ALAMI SEBAGAI UPAYA PREVENTIF PENYEBARAN VIRUS COVID-19."

[3] M. Adi Surya Antara, I. Wayan Arsa Suteja, A. Prabowo, P. Nasional Denpasar dan Jalan Pandu No, and D. Bali, "STERILIZER CHAMBER SEBAGAI SALAH SATU ALAT PENCEGAHAN PENYEBARAN VIRUS COVID-19."

[4] Nurwijayanti. KN and R. Eka Adhytyas, "Garbage Bin Monitoring System Based on the Internet of Things at University Dirgantara Marsekal Suryadarma," International Journal of Education and Management Engineering, vol. 11, no. 2, pp. 1-12, Apr. 2021, doi: 10.5815/ijeme.2021.02.01.

[5] D. Pramanda and Aswardi, "JTEV (JURNAL TEKNIK ELEKTRO DAN VOKASIONAL) Sistem Kendali Kecepatan Motor DC Berbasis Arduino dengan Metode Open Loop," JURNAL TEKNIK ELEKTRO DAN VOKASIONAL, vol. 6, no. 1, pp. 187-198, 2020, [Online]. Available: http://ejournal.unp.ac.id/index.php/jtev/index

[6] Marzuarman, Abdul Hadi, and Jefri Lianda, "BILIK DISINFEKTAN BERBASIS OZON (TANPA CAIRAN KIMIA) SEBAGAI UPAYA PENCEGAHAN PENULARAN COVID-19 DI LINGKUNGAN UPT PUSKESMAS DESA PEMATANG DUKU BENGKALIS,” 2020.

[7] D. A. Aziz and D. Abdulahad Aziz, "Webserver Based Smart Monitoring System Using ESP8266 Node MCU Module," 2018. [Online]. Available: www.ijser.org

[8] F.- Puspasari, I.- Fahrurrozi, T. P. Satya, G.- Setyawan, M. R. al Fauzan, and E. M. D. Admoko, "Sensor Ultrasonik HCSR04 Berbasis Arduino Due Untuk Sistem Monitoring Ketinggian," Jurnal Fisika dan Aplikasinya, vol. 15, no. 2, p. 36, Jun. 2019, doi: 10.12962/j24604682.v15i2.4393.

[9] R. Paradila and M. Arifin, Pengujian Rancangan Sistem Cuci Tangan Tanpa Sentuh Dengan Memanfaatkan E18D80NK Infrared Proximity Sensor dan Solenoid Valve, vol. 6. 2020.

[10] Olivia M. Sinaulan, Yaulie D. Y. Rindengan, and Brave A. Sugiarso, "Perancangan Alat Ukur Kecepatan Kendaraan Menggunakan ATMega 16," E-Journal Teknik Elektro dan Komputer, pp. 60-70, 2015.

[11] B. Boru, H. Siahaan, S. Rizqika Akbar, and D. Syauqy, "Implementasi Modul Antarmuka Perangkat Sensor Dan Komunikasi Pada UART Dan I2C Dengan Fitur Plug and Play," 2018. [Online]. Available: http://j-ptiik.ub.ac.id

[12] D. Auliya Saputra, N. Utami, and R. Setiawan, "RANCANG BANGUN ALAT PEMBERI PAKAN IKAN MENGGUNAKAN MIKROKONTROLER,” 2020.

[13] Yusniati, "Penggunaan Sensor Infrared Switching Pada Motor DC Satu Phasa," 2018.

[14] M. Artiyasa et al., "APLIKASI SMART HOME NODE MCU IOT UNTUK BLYNK," 2020. 